\title{
Editorial RES 1/2016
}

Ist ethnische und religiöse Vielfalt für eine Gesellschaft eine Bereicherung oder eine Belastung? Auf diese Frage in Europa gegenwärtig von höchster Aktualität - gibt es selbstverständlich keine allgemein gültige Antwort. Jedes Land und jede Zeit muss darauf die passende Antwort finden und die Gesellschaft entsprechend gestalten.

Siebenbürgen ist eine der vielen europäischen Regionen, in denen das Zusammenleben verschiedener Volksgruppen über Jahrhunderte eine Selbstverständlichkeit war. Darüber hinaus ist sie auch für eine Tradition der Toleranz zwischen den verschiedenen christlichen Traditionen bekannt. Inwieweit ist dieser Ruf berechtigt? In welchen Bereichen ist von kulturellem Austausch die Rede, wo hingegen herrscht die Abgrenzung vor? Die Beiträge der vorliegenden Nummer von RES werfen einige wenige, aber aufschlussreiche Schlaglichter auf diese Thematik. Dabei ist im Besonderen das Ineinander von religiösen und kulturellen Elementen im Blick.

Der Aufsatz von Ioan Ovidiu Abrudan berührt das Gebiet der Architektur. Es ist auffällig, dass die Glockentürme der orthodoxen oder griechisch-katholischen Kirchen des 18. und 19. Jahrhunderts oft von westlicher Bauart waren - dies dank des Einsatzes von Fachkräften aus der
Is ethnic and religious diversity enriching or impoverishing society? It goes without saying that there is no generally applicable answer to this question - a question of pressing relevance in contemporary Europe. Each country and each age has to find its suitable answer and shape society accordingly.

Transylvania is one of the many European regions in which various ethnic groups have been naturally living together throughout the centuries. Moreover, it is well known for its customary tolerance towards different Christian traditions. To what extent is this a well-deserved reputation? In regard to what areas can we talk about intercultural exchange, and, conversely, where do barriers prevail?

The current issue of RES concentrates on a few, but illuminating aspects of this topic. Particular attention is devoted to the interplay between religious and cultural elements. The article by Ioan Ovidiu Abrudan addresses subjects in the field of architecture. It is noteworthy that the bell towers of 18 thand 19th-century Orthodox and Greek-Catholic churches were frequently built in western architectural style, due to the employment of master builders from the Evan- 
Gemeinschaft der evangelischen Siebenbürger Sachsen.

Ebenso aussagekräftig wie die Architektur ist die Malerei. Die Fresken aus dem 14. - 16. Jahrhundert enthalten eine Fülle von Abbildungen liturgischer Gewänder: Adrian Stoia zeigt auf, dass sie eine Fundgrube für die Erforschung religiöser Traditionen sind, für die es sonst möglicherweise keine anderen Zeugnisse mehr gibt.

Die Ikonographie kann auch zu einem Mittel werden, der schwierigen Situation der eigenen Volksgruppe Ausdruck zu verleihen. Dragos, Boi$c u$ illustriert dies anhand der Passionsdarstellungen der Brüder Grecu vom Beginn des 19. Jahrhunderts, in denen die verschiedenen Rollen (Soldaten, Jünger, Volk) anhand von typischen Merkmalen den siebenbürgischen Volksgruppen zugeordnet werden können. Die Darstellungen werden so zu einem stillen, aber dauerhaften Protest.

Die nächsten beiden Aufsätze wenden sich der Musik zu. In der Tradition der orthodoxen Rumänen spielt das Liedgut, das die grossen kirchlichen Feste begleitet, eine wichtige Rolle. Kultur und Glaube, christliche und vorchristliche Motive sind eng miteinander verbunden. Dan Alexandru Streza analysiert dessen vielfältige Formen und Bedeutung.

Liturgie und Lieder sind eng an die Sprache gebunden, in der sie entstanden sind. Wo diese sich ändert, steht die Kirche vor grossen Herausforderungen. gelical communities of Transylvanian Saxons.

Equally significant as architecture is painting. 14th- and 16-century frescoes depict a wealth of liturgical vestments: Adrian Stoia shows that they are a rich source for the research of religious traditions for which no other evidence might be available.

Iconography can also be used to give expression to the difficult circumstances an ethnic group might go through. Dragos, Boicu illustrates this using the early 19th-century portrayal of the Passion by the Grecu brothers, in which various roles (soldier, disciple and bystander) are identified by characteristics typical to different Transylvanian ethnic groups. Representation becomes a silent, but lasting protest.

The next two articles turn to music. The treasury of songs that accompany major Church Feasts plays an important role in the Romanian Orthodox tradition. Culture and faith, Christian and pre-Christian motifs are closely entwined. Dan Alexandru Streza analyses the multitude of forms and meanings found in this music.

Liturgy and songs are closely connected to the language they were created in. Church faces great challenges when this language changes. To demonstrate this, Gerhild Ingrid Rudolf employs as an example the creation and use of the bilingual 
Gerhild Ingrid Rudolf zeigt dies am Beispiel von Entstehung und Gebrauch des zweisprachigen Liederbuches der evangelischen Kirche in Rumänien.

Im Essay von Hans Bruno Fröhlich kommt ein wesentliches Element des Zusammenlebens im multikulturellen Siebenbürgen zum Ausdruck, nämlich die bewussten ökumenischen Bestrebungen von kirchenleitenden Persönlichkeiten. Er tut dies anhand von zwei gegenwärtigen Beispielen der evangelischen Kirche.

Unter der Rubrik „Weitere Aufsätze" wird schliesslich ein Aspekt aus dem Werk von Dumitru Stăniloae gewürdigt: Ciprian Ioan Streza beschreibt die Aufnahme und Neuinterpretation der Lehre vom ewigen Opfer Christi bei Kyrill von Alexandrien.

Enthält die Geschichte und die Gegenwart Siebenbürgens etwas, das als Beitrag an die drängenden Fragen Europas von heute verstanden werden kann? So klein der Ausschnitt der behandelten Themen in dieser Nummer von RES auch notwendigerweise ist, so wird eines doch deutlich: die fruchtbarsten Zeiten und Entwicklungen waren diejenigen, in denen sich die verschiedenen Gruppen nicht gegeneinander abschlossen, sondern im Austausch miteinander standen und so fähig waren, Wandlungsprozesse zu gestalten und sich darin gegenseitig zu unterstützen. songbook by the Evangelical Church in Romania.

The essay by Hans Bruno Fröhlich highlights an essential element of multiculturalism in Transylvania, namely the mindful ecumenical efforts of leading Church figures, exemplified by two contemporary Evangelical public figures.

Further contributions, under the heading "Additional Articles", honour the work of Dumitru Stăniloae: Ciprian Ioan Streza describes the reception and re-interpretation of Cyril of Alexandria's teaching of Christ's Perpetual Sacrifice.

Is there something in Transylvania's past or present that could be seen as a contribution to the pressing questions of contemporary Europe? As small as it may be the selection of topics to be found in the current issue of RES, it nonetheless allows for an undisputable conclusion: the most prolific periods and developments were those during which different groups did not erect barriers against each other, but rather engaged in mutual exchanges that enabled them to shape their own transformation and support each other along the process. 